\title{
ANALISIS SATIRE DAN SARKASME DALAM DEBAT CAPRES 2019 DAN IMPLEMENTASINYA TERHADAP PEMBELAJARAN DI SMA
}

\author{
Siti Farmida $^{1}$, Ediwarman $^{2}$, Sundawati Tisnasari ${ }^{3}$ \\ Pendidikan Bahasa Indonesia, FKIP, Universitas Sultan Ageng Tirtayasa \\ Kampus II Jalan Ciwaru Raya No. 25, Kota Serang \\ Email: Sitifarmidaa22@gmail.com
}

\begin{abstract}
This study discusses the sarcasm and satiric speech in the 2019 presidential candidates debate and the implementations of learning in high school. The purpose of this study are (1) To describe the forms of the language style of the sarcasm and satire in the 2019 presidential candidates debate, (2) To know the use propose of the language style of the sarcasm and satire in the 2019 presidential candidates debate. The method used in this research is descriptive qualitative method. Technique of collecting data in this researh is observation technique and writing technique. The data in this research is sarcasm and satiric speech in the 2019 presidential candidates debate. Based on the result of the research, there are 78 data, 30 data consist of satire speech and 48 data consist of sarcasm speech. The use purpose of satire speech from expressive speech acts there is 23 data, that is: criticism (9), refusal (4), rebuke (1), feel objected (1), to clarify (5), complaint (1), quip (1), Support (1). The use purpose of satire speech from directive speech acts there is 7 data, that is: appeal (3), warning (1), advice (2), to expect (1). The use purpose of sarcasm speech from expressive speech acts there is 47 data, that is: accusation (7), quip (12), criticism (11), suspects (2), warning (2), censure (2), blaming (4), deny (2), underestimate (1), pride oneself (1), anger (1), disagree (1), rebukr (1). The use purpose of sarcasm speech from directive speech acts there is 1 data, that is: advice (1).
\end{abstract}

\section{Keywords: Satire, Sarcasm, Illocutionary speech acts, the 2019 presidential candidates debate}

\begin{abstract}
ABSTRAK
Penelitian ini membahas gaya bahasa satire dan sarkasme dalam debat Capres 2019 serta impelemntasinya terhadap pembelajaran di SMA. Tujuan penelitian ini adalah (1) Mendeskripsikan bentuk gaya bahasa satire dan sarkasme dalam debat calon presiden 2019, (2) Mengetahui tujuan penggunaan gaya bahasa satire dan sarkasme dalam debat calon presiden 2019. Metode yang digunakan dalam penelitian ini adalah deskriptif kualitatif. Teknik pengumpulan data dalam penelitian ini adalah teknik simak dan catat. Data dalam penelitian ini adalah gaya bahasa satire dan sarkasme pada debat Capres 2019. Berdasarkan hasil penelitian ditemukan 78 data dengan gaya bahasa satire berjumlah 30 data dan gaya bahasa sarkasme berjumlah 48 data. Tujuan gaya bahasa satire dari tindak tutur ekspresif ada 23 data, yaitu: mengkritik (9), menolak (4), menegur (1), merasa keberatan (1), mengklarifikasi (5), mengeluh (1), menyindir (1), mendukung (1). Tujuan tuturan Satire dari tindak tutur direktif ada 7 buah, yaitu: mengajak (3), memperingatkan (1), menyarankan (2), mengharapkan (1). Tujuan gaya bahasa sarkasme dari tindak tutur ekspresif ada 47 data, yaitu: menuduh (7), menyindir (12), mengkritik (11), mencurigai (2), memperingatkan (2), mengecam (2), menyalahkan (4), membantah (2), meremehkan (1), membanggakan diri (1), memarahi (1), tidak setuju (1), menegur (1). Tujuan gaya bahasa sarkasme dari tindak tutur direktif ada 1, yaitu: menyarankan (1).
\end{abstract}

Kata Kunci: Satire, Sarkasme, Tindak tutur ilokusi, debat Capres 2019 
How to Cite: Siti Farmida, Ediwarman, E., \& Tisnasari , S. (2021). Analisis Satire dan Sarkasme Dalam Debat Capres 2019 dan Implementasinya terhadap Pembelajaran di SMA. Bahtera Indonesia; Jurnal Penelitian Bahasa Dan Sastra Indonesia , 6(2), 189-202. https://doi.org/10.31943/bi.v6i2.131

\section{DOI: https://doi.org/10.31943/bi.v6i2.131}

\section{PENDAHULUAN}

Penggunaan bahasa dalam seluruh aktifitas manusia merupakan bentuk bahasa sebagai alat atau media komunikasi antarmanusia. Komunikasi yang dilakukan oleh seseorang harus bisa dipahami oleh lawan bicaranya karena hal tersebut merupakan tolak ukur keberhasilan tersampaikannya perasaan, pikiran atau hal apapun yang ingin disampaikan. Salah satu aspek kehidupan manusia yang tidak terlepas dari adanya proses komunikasi adalah politik. Politik merupakan kegiatan yang diarahkan untuk mendapatkan dan mempertahankan kekuasaan di masyarakat. Bahasa sebagai alat politik digunakan oleh pihak tertentu untuk meraih kekuasaaan. Bahasa mampu mengubah pola pikir manusia, memerintah pikiran manusia bahkan merusak pikiran manusia atau disebut sebagai alat kontrol politik.

Alasan inilah yang membuat individu memanfaatkan bahasa untuk kepentingan pribadi. Misalnya, saat melakukan debat antar lawan. Hal itu dilakukan tak lain sebagai bentuk tindakan persuasif untuk menarik dukungan masyarakat. Ada beberapa strategi bahasa yang biasanya digunakan kandidat untuk memenangkan debat, salah satunya dengan menggunakan gaya bahasa satire dan sarkasme. Satire dan sarkasme keduanya merupakan bentuk ungkapan kiasan berupa sindiran. Yang membedakan ialah satire berupa sindiran agak halus karena sindirannya tidak diungkapkan secara langsung dan mengandung kritikan/kelemahan demi sebuah perbaikan kepada orang yang dituju.

Sedangkan sarkasme berupa sindiran keras diungkapkan secara langsung sehingga cenderung membuat orang yang mendengarnya tersinggung dan sakit hati. Penggunaan bahasa satire dan sarkasme dalam politik tersebut akan memunculkan beragam persepsi makna bagi orang lain. Hal ini tentu menjadi suatu permasalahan yang harus dikaji lebih lanjut. Penelitian ini akan berfokus pada debat Capres 2019 yang tayang serentak di Indonesia pada bulan April 2019, 
alasannya karena adanya fenomena menarik dalam debat calon presiden 2019.

Fenomena tersebut adalah ketika para kandidat saling perang opini dengan gaya komunikasi yang saling sahut dan saling sindir secara tajam hingga menyulut emosi publik. Terkait dengan permasalahan tersebut peneliti tertarik untuk mengupas atau mengkaji lebih dalam bentuk gaya bahasa satire dan sarkasme dalam debat calon presiden 2019 dengan memanfaatkan teori tindak tutur ilokusi milik Searle sebagai pendekatannya untuk mengungkap tujuan penggunaan gaya bahasa satire dan sarkasme dalam debat calon presiden 2019.

\section{KAJIAN TEORI}

Leech (dalam Jumanto, 2017: 39) pragmatik adalah studi tentang bagaimana tuturan memiliki makna dalam situasi. Sementara itu, Djajasudarma (2012: 60) menjelaskan bahwa pragmatik sebagai studi terhadap makna ujaran dalam situasi atau konteks tertentu. Definisi lebih lengkap diungkapkan oleh Jumanto (2017: 42) yang menyatakan bahwa pragmatik adalah studi tentang makna atas penggunaan bahasa dalam komunikasi antara penutur dan petutur sesuai dengan konteks, baik linguistik maupun situasi dalam lingkup komunitas bahasa tertentu.
Ketiga ahli di atas dalam definisi pragmatik secara garis besar sama-sama menyoroti tentang adanya konteks tuturan karena sangat penting peranannya dalam kajian pragmatik. Seperti yang telah dijelaskan di atas, konteks adalah beberapa pengetahuan yang melingkupi suatu percakapan. Konteks menentukan suatu makna ujaran. Dalam berbahasa, harus memperhatikan konteks situasi yang menyertai ujaran agar dapat memahami maksud kalimat atau ujaran dengan jelas.

Dengan adanya pemahaman yang jelas tentang konteks, kecil kemungkinan terjadinya kesalahpahaman antara penutur dan mitra tutur. Berdasarkan pendapatpendapat para ahli di atas dapat disimpulkan bahwa pragmatik merupakan ilmu yang mengkaji makna ujaran dalam peristiwa tuturan tertentu. Oleh sebab itu, tidak bisa dilepaskan dari konteksnya atau pragmatik adalah ilmu bahasa yang terikat konteks. Pragmatik memiliki beberapa cabang kajian, yaitu: (1) Tindak tutur atau tindak bahasa, (2) Maksim kerja sama Grice, (3) Maksimmaksim kesantunan, (4) Praanggapan, (4) implikatur, (5) Entailment, dan (6) Prinsip kelakar dan prinsip ironi.

Salah satu kajian pragmatik adalah tindak tutur atau tindak bahasa. Tindak tutur adalah cabang pragmatik yang mengkaji tentang ungkapan bahasa dalam kaitannya dengan 
tindakan maupun ucapan atau yang dikenal dengan "speech act." Austin (1962) dalam Juansah \& Andhika (2017: 25) menyebutkan bahwa dalam segala situasi, ketika berbicara atau berkomunikasi, kita tidak hanya menyatakan kalimat saja, tetapi juga melakukan suatu tindakan.

Sejalan dengan pendapat Austin, Yule (1996: 47) menyatakan bahwa tindak tutur adalah tindakan yang dilakukan melalui ujaran. Jadi, dapat disimpulkan bahwa tindak tutur suatu ujaran yang terdapat tindakan di dalamnya dengan tak lepas mempertimbangkan aspek situasi tutur. John R. Searle (1983) dalam Rahardi (2007: 70) mengelompokkan tiga jenis tindak tutur. Ketiga macam tindak tutur tersebut, yaitu: 1) Tindak tutur lokusi (the act of saying something), berfungsi berfungsi untuk memberitahukan atau menginformasikan sesuatu, 2) Tindak tutur ilokusi (the act of doing something), tindak melakukan sesuatu dengan maksud dan fungsi pula, 3) Tindak tutur perlokusi (the act of effecting someone), tindakan menimbulkan pengaruh kepada seseorang.

Tindak ilokusi menghendaki adanya tindakan dari mitra tutur ketika mendengar perkataan dari penutur. Searle (1983) dalam Rahardi (2007: 72) menggolongkan tindak tutur ilokusi menjadi lima macam, yaitu:
1. Tindak tutur asertif, yakni bentuk ungkapan yang mengikat penutur pada kebenaran proposisi yang diungkapkan, misalnya menyatakan, menyarankan, dll.

2. Tindak tutur direktif, yaitu dimaksudkan untuk membuat pengaruh agar mitra tutur melakukan sesuatu tertentu. Misalnya, memerintah, memohon, dll.

3. Tindak tutur ekspresif, yakni untuk menyatakan atau menunjukkan sikap psikologis penutur terhadap suatu keadaan. Misalnya saja, menyalahkan, mengejek, dll.

4. Tindak tutur komisif, untuk menyatakan janji atau penawaran, misalnya saja berjanji, bersumpah, dll.

5. Tindak tutur deklarasi, yakni menghubungkan isi tuturan dengan kenyataannya, misalnya memberi nama, mengangkat dll.

\section{Debat}

Debat adalah perbincangan antara beberapa orang yang membahas suatu masalah dan masing-masing mengemukakan pendapatnya atau alasan (KBBI, 2005: 240). Sementara itu, menurut Nurcahyo (2013: 3) menyatakan bahwa debat merupakan pertentangan argumentasi. Untuk setiap isu, pasti terdapat berbagai sudut pandang terhadap isu tersebut: alasan-alasan mengapa seseorang dapat mendukung atau tidak mendukung isu. 
Sedangkan menurut Pratama (2018: 6) menjelaskan bahwa debat sebagai kegiatan adu argumentasi antara dua pihak atau lebih (perorangan atau kelompok) dalam berusaha mendiskusikan dan memutuskan masalah serta mengkaji perbedaan. Dapat disimpulkan bahwa debat merupakan adu argumen untuk menentukan baik tidaknya suatu usul tertentu yang didukung oleh suatu pihak yang disebut pendukung atau tim pro dan ditolak, disangkal oleh pihak lain yang disebut penyangkal atau tim kontra.

Tujuan dari debat adalah untuk mengeksplorasi alasan-alasan di belakang setiap sudut pandang. Agar alasan tersebut dapat dimengerti secara persuasif, pembicara dalam suatu debat seharusnya menyampaikan argumentasinya dengan kemampuan komunikasinya yang baik. Berbagai alasan yang mendorong orang untuk berdebat, antara lain meyakinkan orang lain bahwa opini dia lebih baik, mendengarkan opini orang lain terhadap suatu isu, menemukan solusi yang terbaik untuk suatu masalah, dan lain-lain.

\section{Satire}

Satire masuk ke dalam jenis gaya bahasa langsung tidaknya makna dan merupakan gaya bahasa kiasan karena menggunakan ungkapan-ungkapan simbolis yang tidak langsung diketahui maknanya dengan hanya melihat kata-katanya saja. Dengan kata lain, maksud satire tidak akan terlihat langsung setelah kita mendengar hanya dari kata-kata yang menyusunnya saja tetapi orang harus mencari makna di luar rangkaian kata-kata tersebut. Prasetyono (2011: 42) mengungkapkan bahwa satire memiliki makna, yaitu gaya bahasa yang menyatakan sindiran terhadap suatu keadaan atau seseorang. Gaya bahasa satire juga merupakan gaya bahasa sejenis argumen atau puisi atau karangan yang berisi kritik sosial baik secara terang-terangan maupun terselubung (Murti, 2013: 275).

Sementara itu, Keraf (2009: 144) menyatakan Satire ini merupakan ungkapan yang digunakan oleh seseorang untuk menertawakan atau menolak sesuatu hal. Dalam hal ini, bentuk satire tidak perlu harus bersifat ironis. Hal ini dikarenakan satire mengandung kritikan mengenai kelemahan yang dimiliki oleh manusia. Tujuan utamanya agar manusia mengadakan perbaikan secara etis maupun secara estetis.

Jadi, dapat disimpulkan satire adalah gaya bahasa yang berfungsi untuk menyatakan sindiran terhadap suatu keadaan atau seseorang secara tidak langsung dengan tujuan untuk memberikan perbaikan terhadap orang yang dikritiknya. Dengan kata lain, ungkapan satire ini dimaksudkan untuk 'menampar' pemikiran orang agar melihat sisi lain secara lebih kritis. 


\section{Tipe-Tipe Satire}

The Art And Popular Culture Encyclopedia dalam Simpson (dikutip dari tesis Manjarreki Kadir 2018: 28-29) menegaskan bahwa satire biasanya memiiki target tertentu yang dapat berupa orang atau sekelompok orang atau sekelompok orang, gagasan maupun sikap, institusi, maupun praktik sosial. Menurut Simpson (2004: 71) target satire dibedakan menjadi empat, yaitu:

1. Episodic, adalah satire yang adalah satire yang targetnya berupa kondisi tindakan, atau peristiwa khusus yang terjadi di ranah masyarakat seperti aspek sosial kemasyarakatan, politik, maupun agama.

2. Personal, adalah satire yang targetnya adalah individu tertentu, ditujukan pada kepribadian seseorang terutama sifat streotipe dan arketipe perilaku manusia. Satire tipe ini terdapat aspek sifat, kondisi, dan perilkau seseorang.

3. Experential, adalah satire yang targetnya adalah aspek kondisi dan pengalaman manusia yang bersifat menetap, sebagai lawan dari episode dan peristiwa tertentu.
Satire ini terdapat aspek pengalaman hidup.

4. Textual, adalah satire yang targetnya adalah kode linguistik sebagai objek yang diserang. Tipe ini lebih beragam, karena ungkapan tipe ini dapat digunakan untuk menyerang dalam aspek agama, politik, budaya, dan yang lainnya.

\section{Sarkasme}

Sama dengan satire, sarkasme juga termasuk ke dalam jenis gaya bahasa berdasarkan langsung tidaknya makna, atau bahasa yang sudah memiliki perubahan makna dan merupakan gaya bahasa kiasan.

Keraf (2009: 143) menyatakan bahwa sarkasme merupakan suatu acuan yang lebih kasar dari ironi dan sinisme. Ia adalah suatu acuan yang mengandung kepahitan dan celaan yang getir. Sarkasme dapat saja bersifat ironis, dapat juga tidak, tetapi yang jelas adalah bahwa gaya ini selalu akan menyakiti hati dan kurang enak didengar.

Gaya bahasa sarkasme adalah gaya bahasa yang tujuaannya dimaksudkan untuk menyindir, atau menyinggung seseorang bahkan memojokkan lawan. Jadi, dapat dipahami bahwa sarkasme adalah gaya bahasa sindiran langsung, tajam atau keras yang dapat melukai seseorang. 
Gaya bahasa ini cenderung akan menyakiti hati seseorang jika diungkapkan. Berbeda dengan satire yang sindirannya secara halus, sarkasme cenderung sindiran secara langsung maupun kata sebaliknya yang berlawanan dengan maksud yang ingin disampaikan.

\section{Penanda Sarkasme}

Terdapat beberapa penanda yang dapat dijadikan acuan dalam memudahkan untuk menganalisis gaya bahasa sarkasme. Berikut ini adalah gaya bahasa berdasarkan teori Elizabeth Camp (1994) dalam jurnal Irene Dinari (2015: 498-499) tahun 3025 berjudul "Jenis-Jenis dan Penanda Majas Sarkasme dalam novel The Return Of Sherlock Holmes". Berikut beberapa penanda gaya bahasa sarkasme:

1. Sarkasme Proposisi

Sarkasme proposisi ini merupakan sarkasme yang paling jelas bentuknya. Karena dia merupakan sarkasme yang mengarah langsung maksud atau tujuan dari pembicara yang memang bertujuan "menyindir".

\section{Sarkasme Leksikal}

Sarkasme leksikal berbeda dengan sarkasme proposisi. Jika sarkasme proposisi mengarah langsung kepada maksud tujuan, sarkasme leksikal lebih bersifat pragmatis.

3. Sarkasme Prefiks

Sarkasme prefiks mirip dengan sarkasme proposisi, tetapi sarkasme prefiks hanya mengkombinasikan pernyataan sarkasme dengan kalimat deklaratif. Jika dalam sarkasme proposisi sangat kuat dengan implikatur yang diucapkan penuturnya dan berlawanan dengan maksud yang ingin diutarakan, maka pada sarkasme prefiks lebih cenderung tidak menimbulkan kebingungan.

4. Sarkasme Ilokusi

Pada sarkasme ilokusi, penutur mengungkapkan kalimat yang berbeda dengan maksud dan tujuannya. Sarkasme pada jenis ini akan berhasil jika penerima tuturan mengerti maksud penutur. Jenis ini, sarkasme tidak hanya dilihat sebagai elemen di dalam suatu tuturan, tetapi juga sebagai satu kesatuan yang utuh termasuk tindak tutur lain menyertainya. Sarkasme ilokusi meliputi keseluruhan implikatur umum bahkan dalam lingkup yang khusus, seperti tuturan yang menyatakan rasa iba, pujian dan lain-lain.

\section{METODE PENELITIAN}

Penelitian ini bertujuan untuk mendeskripsikan bentuk satire dan sarkasme dalam debat capres 2019. Dengan demikian, untuk mencapai tujuan tersebut digunakan 
desain penelitian deskriptif kualitatif karena data yang diteliti merupakan data yang berbentuk kata-kata, kalimat sehingga bisa mempertimbangkan bahwa data ini memang layak menggunakan metode deskriptif kualitatif.

Teknik yang digunakan dalam penelitian ini meliputi teknik pengumpulan data, teknik analisis data, teknik penyajian hasil analisis data, dan teknik pemeriksaan keabsahan data. Teknik pengumpulan data dalam penelitian ini adalah teknik simak dan catat.

\section{Data dan Sumber Data Penelitian}

Sumber data dalam penelitian ini adalah video debat calon presiden 2019 yang didapat dari situs www.youtube.com.

Peneliti mengambil sejumlah 4 video debat capres 2019 yang kemudian akan diobservasi dan diambil data yang mengandung gaya bahasa satire dan sarkasme sebagai sumber data. Dari kelima video debat capres 2019 yang telah disiarkan, peneliti hanya fokus mengambil 4 video, yaitu: 1) Debat capres dan cawapres putaran pertama tanggal 17 Januari 2019, 2) Debat capres putaran kedua tanggal 17 Februari 2019, 3) Debat capres putaran keempat tanggal 30 Maret 2019, 4) Debat capres dan cawapres putaran kelima tanggal 13 April 2019. Sementara itu, debat putaran ketiga, yaitu debat cawapres Ma'ruf Amin VS Sandiaga
Uno pada tanggal 17 Maret 2019 tidak diperhitungkan karena peneliti hanya akan fokus mengambil data berupa dialog debat calon presiden saja.

\section{ANALISIS DAN HASIL}

Dalam bab ini akan dipaparkan hasil penelitian yang diperoleh berdasarkan hasil pengumpulan data dan penganalisisan data. Hasil penelitian yang dipaparkan berupa bentuk gsys bahasa satire dan sarkasme serta tujuan penggunaannya melalui teori tindak tutur ilokusi John R. Searle (1983) dalam debat capres 2019.

\section{Analisis Data}

1. Analisis Data Gaya Bahasa Satire serta Tujuan Penggunaannya

\section{Data 2}

\section{Satir/2/DC1/TTE/Mengkritik}

Prabowo: "Tapi yang jelas kenyataannya sekarang tumpang tindih menumpuk begitu banyak peraturan. Perlu ada bantuan pakar-pakar untuk membantu pemerintah. Kita ingin percepatan. Selalu ini di Indonesia masalah selalu banyak, masalah terbesar. Kita ingin terobosan harus ada terobosan."

Tujuan Satire: Tindak tutur mengkritik.

Analisis Data: Data di atas berisi pernyataan dari Pak Prabowo untuk Pak Jokowi. 
Pernyataan tersebut terdapat gaya bahasa satire.

Seperti yang disampaikan oleh Keraf (2009: 144) Satire merupakan ungkapan yang digunakan oleh penutur untuk menertawakan atau menolak sesuatu hal. Hal ini dikarenakan satire mengandung kritikan mengenai kelemahan yang dimiliki oleh manusia. Tujuan utamanya agar manusia mengadakan perbaikan secara etis maupun estetis.

Berdasarkan pengertian di atas, gaya bahasa satire ini masuk kedalam tipe satire episodic, adalah satire yang targetnya berupa kondisi tindakan, atau peristiwa khusus yang terjadi di ranah masyarakat seperti aspek sosial seperti aspek sosial kemasyarakatan, politik, maupun agama (Simpson, 2004: 71). Kalimat di atas berisi kritikan aspek politik. Satire jelas terlihat dalam kalimat "Perlu ada bantuan pakar-pakar untuk membantu pemerintah, kita ingin percepatan. Selalu ini di Indonesia masalah selalu banyak, masalah terbesar. Kita ingin terobosan harus ada terobosan."

Kalimat tersebut berisi kritikan Pak Prabowo terhadap jawaban yang dilontarkan oleh lawannya bahwa perlu adanya perbaikan-perbaikan untuk membantu pemerintah dalam menghadapi masalah yang banyak.

Tujuan penggunaan satire tersebut dilihat dalam tindak tutur Searle (1983) dalam
Rahardi (2007: 72). Tindak tutur yang terkandung dalam kalimat tersebut merupakan tindak tutur ekspresif. Tindak tutur ekspresif adalah bentuk tuturan yang berfungsi untuk menyatakan atau menunjukkan sikap psikologis penutur terhadap suatu keadaan. Sikap psikologis dalam pernyataan tersebut merupakan sikap mengkritik.

Jadi, data di atas merupakan bentuk gaya bahasa satire tipe episodic dengan tujuan menolak.

2. Analisis Data Gaya Bahasa Sarkasme serta Tujuan Penggunaannya

\section{Data 42}

\section{Sarkasme/42/DC1/TTE/Menyalahkan}

Prabowo: "Kami yakin negara ini sangatsangat kaya tapi terjadi kebocoran-kebocoran kekayaan. Kekayaan kita mengalir ke luar negeri, ini bukan salah siapa saja, ini salah kita bersama sebagai bangsa, dan ini kesalahan elit yang membiarkan ini sudah puluhan tahun.”

Tujuan Satire: Tindak tutur ekspresif menyalahkan

Analisis Data: Data di atas merupakan pernyataan yang disampaikan oleh Pak Prabowo untuk menanggapi pernyataan Pak Jokowi. 
Pernyataan tersebut terdapat gaya bahasa sarkasme. Seperti yang telah dijelaskan oleh Keraf (2009: 143) bahwa sarkasme adalah gaya bahasa yang cenderung bersifat menyinggung atau bahkan menyakiti hati seseorang. Gaya bahasa sarkasme di atas masuk ke dalam sarkasme proposisi. Sarkasme proposisi ini merupakan sarkasme yang paling jelas bentuknya. Karena dia merupakan sarkasme yang mengarah langsung maksud atau tujuan dari pembicara yang memang bertujuan "menyindir". (Camp, 1994 dalam Dinari, 2015: 498-499). Data di atas menunjukkan ungkapan tajam dan keras kepada elit terdahulu.

Sementara unuk tujuan penggunaan tuturan sarkasme tersebut dapat dilihat melalui tindak tutur Searle (1983) dalam Rahardi (2007: 72). Kalimat tersebut masuk ke dalam tindak tutur ekspresif.

Tindak tutur ekspresif adalah bentuk tuturan yang berfungsi untuk menyatakan atau menunjukkan sikap psikologis seseorang terhadap suatu keadaan. Sikap psikologis yang terkandung dalam pernyataan di atas merupakan sikap menyalahkan. Kalimat sarkasme tersebut Pak Prabowo dengan tujuan untuk menyatakan sikap menyalahkan terhadap elit terdahulu yang telah memunculkan permasalahan kebocoran kekayaan negara ke luar negeri.
Jadi, data di atas merupakan bentuk gaya bahasa sarkasme proposisi yang bertujuan untuk menyalahkan.

\section{PEMBAHASAN}

Penelitian ini memiliki nilai-nilai yang telah didapat melalui hasil penelitian yang tentunya sesuai dengan fokus dalam penelitian.

\section{Pendeskripsian Bentuk Gaya Bahasa Satire dan Sarkasme dalam Debat Capres 2019}

Bentuk gaya bahasa satire dan sarkasme merupakan wujud penggunaan bahasa satire dan sarkasme secara nyata dalam percakapan. Gaya bahasa satire dan sarkasme digunakan seseorang untuk tujuan tertentu. Penelitian ini berfokus pada ungkapan yang diujarkan oleh calon presiden dalam debat 2019. Hasilnya ditemukan sebanyak 78 data dengan total gaya bahasa satire sebanyak 30 data dan gaya bahasa sarkasme 48 data.

Gaya bahasa satire pada debat capres 2019, ditemukan tiga macam bentuk, yaitu episodic, personal dan textual. Sedangkan gaya bahasa sarkasme pada debat capres 2019, ditemukan bentuk sarkasme proposisi.

Pada debat capres 2019, gaya bahasa satire mengandung ungkapan sindiran, teguran ataupun kritikan dan diungkapkan secara halus dan implisit dengan harapan dapat membangun atau menyadarkan 
seseorang lewat kehalusan kata-kata dan makna yang tersembunyi didalamnya. Sedangkan gaya bahasa sarkasme lebih kearah ungkapan sindiran yang keras, secara eksplisit atau terus terang bahkan cenderung dapat menyakiti hati seseorang.

2. Penafsiran Tujuan dari Bentuk Gaya Bahasa Satire dan Sarkasme dalam Debat Capres 2019

Telah disebutkan sebelumnya bahwa pemakaian gaya bahasa satire dan sarkasme tentunya memiliki tujuan dan maksud yang hendak disampaikan. Berdasarkan analisis data yang telah dilakukan, ditemukan adanya 78 data dengan total gaya bahasa satire sebanyak 30 data dan gaya bahasa sarkasme 48 data.

Ditemukan pula tujuan penggunaan gaya bahasa satire setelah dianalisis menggunakan teori tindak tutur ilokusi. Dalam debat capres 2019 ini, tujuan penggunaan satire dan sarkasme lebih banyak mengungkapkan tindak tutur ekspresif dan tindak tutur direktif.

Gaya bahasa satire yang ditemukan sebanyak 30 data memiliki tujuan yang dilihat dari tindak tutur ekspresif 23 data dan direktif 7 data, serta gaya bahasa sarkasme sebanyak 48 dengan tujuan penggunaan gaya bahasa sarkasme dikategorikan menjadi tindak tutur ekspresif 47 data dan direktif 1 data dalam debat capres 2019. Berikut uraian lebih jelas mengenai hasil penelitian yang diemukan.
1) Gaya bahasa satire dalam debat capres 2019 yang termasuk dalam tindak tutur ekspresif dan memiliki beberapa tujuan, yaitu: mengkritik (9), menolak (4), menegur (1), merasa keberatan (1), mengklarifikasi (5), mengeluh (1), menyindir (1), mendukung (1), jadi total 23 data.

Pada penelitian ini menunjukkan data dalam debat capres 2019 terdapat pernyataan yang tujuannya merupakan ungkapan perasaan seseorang. Pada analisis penelitian ini, fungsi ekspresif yang ditemukan kebanyakan adalah konteks tujuan mengkritik. Dikarenakan pada ajang debat kritik mengkritik adalah yang paling sering dan lazim digunakan.

Debat adalah adu argumen antar lawan. Satire adalah ungkapan membangun yang diungkapkan seseorang untuk menonjolkan citra dirinya, dalam hal ini kritikan positif akan memberikan pengaruh positif terhadap dirinya dan menjadi nilai plus di mata publik. Maka tak heran jika mengkritik adalah yang paling sering digunakan ketika berdebat.

Karena sesuai dengan konteks dalam debat yaitu, saling beradu argumen untuk melihat siapa yang pantas dalam menjabat sebagai kepala negara Republik Indonesia.

2) Gaya bahasa satire dalam debat capres 2019 yang termasuk dalam tindak tutur direktif dan memiliki beberapa tujuan, 
yaitu: mengajak (3) memperingatkan (1), menyarankan (2), mengharapkan (1), jadi total 7 buah.

Hal ini menunjukkan bahwa pernyataan dalam debat Capres 2019 terdapat gaya bahasa yang ditunjukkan langsung kepada mitra tutur agar melakukan tindakan tertentu.

Pada analisis penelitian ini fungsi direktif yang ditemukan lebih banyak adalah konteks tujuan mengajak. Karena sesuai dengan konteks debat yang merupakan ajang terbuka yang dilihat semua warga negara, ajang ini tentu menjadi ajang yang tepat untuk mengajak publik melakukan apa yang diinginkan oleh pembicara.

3) Sementara itu, Total gaya bahasa sarkasme sebanyak 48. Yakni gaya bahasa sarkasme dalam debat capres 2019 yang termasuk dalam tindak tutur ekspresif dan memiliki beberapa tujuan, yaitu: menuduh (7), menyindir (12), mengkritik (11), mencurigai memperingatkan (2), mengecam (2), menyalahkan (4), membantah (2), meremehkan (1), membanggakan diri (1), memarahi (1), tidak setuju (1), menegur (1), jadi total 47 buah.

Dari hasil penelitian dapat diketahui bahwa dalam debat Capres 2019 gaya bahasa sarkasme yang diungkapkan lebih banyak menghasilkan tindak tutur ekspresif, menunjukkan bahwa percakapan dalam debat capres 2019 ini terdapat lebih banyak pernyataan yang tujuannya merupakan ungkapan perasaan seseorang.

Pada analisis penelitian ini, fungsi ekspresif yang ditemukan lebih banyak adalah konteks tujuan menyindir. Ini membuktikan bahwa sarkasme lebih sering mengeluarkan ekspresi diri dari si pembicara. Pada data-data yang telah dikemukakan sebelumnya, terlihat jelas sindiran-sindiran yang diungkapkan, baik disengaja maupun tidak disengaja.

Disengaja karena terpancing akibat pernyataan lawan bicara yang menyinggungnya, tak disengaja karena ingin memenangkan perdebatan dengan cara menjatuhan lawan.

Dengan begitu gaya bahasa sarkasme tersebut bukan hal yang tabu untuk dilakukan selama masih dalam batas wajar, karena dalam dunia politik hal tersebut sudah biasa, mempengaruhi penonton dengan menonjolkkan hal-hal yang belum tentu benar, atau isu-isu yang dapat memancing lawan dan menjatuhkannya.

4) Sedangkan gaya bahasa sarkasme dalam debat capres 2019 yang termasuk dalam tindak tutur direktif hanya memiliki satu tujuan, yaitu: Menyarankan (1).

\section{PENUTUP}


Berdasarkan hasil penelitian dan pembahasan maka dapat disimpulkan sebagai berikut:

1. Jumlah gaya bahasa yang mengandung satire dan sarkasme terdapat dalam debat capres 2019, yakni 78 data dengan gaya bahasa satire berjumlah 30 data dan gaya bahasa sarkasme berjumlah 48 data. Berdasarkan hasil penelitian, gaya bahasa satire dalam debat capres 2019 ditemukan tiga macam bentuk, yaitu episodic, personal dan textual. Sedangkan gaya bahasa sarkasme pada debat capres 2019, ditemukan bentuk sarkasme proposisi.

2. Gaya bahasa satire dalam debat capres 2019 yang termasuk dalam tindak tutur ekspresif kesemuanya memiliki beberapa tujuan, yaitu: mengkritik (9), menolak (4), menegur (1), merasa keberatan (1), mengklarifikasi (5), mengeluh (1) menyindir (1), mendukung (1), jadi total 23 data. Tuturan satire dalam debat capres 2019 yang termasuk dalam tindak tutur direktif dan memiliki beberapa tujuan, yaitu: mengajak memperingatkan (1), menyarankan (2), mengharapkan (1), jadi total 7 data.

3. Gaya bahasa sarkasme sebanyak 48 data. Yakni gaya bahasa sarkasme dalam debat capres 2019 yang termasuk dalam tindak tutur ekspresif dan memiliki beberapa tujuan, yaitu: menuduh (7), menyindir (12), mengkritik (11), mencurigai (2), memperingatkan (2), mengecam (2), menyalahkan (4), membantah (2), meremehkan (1), membanggakan diri (1), memarahi (1), tidak setuju (1), menegur (1), jadi total 47 data.

4. Gaya bahasa sarkasme dalam debat capres 2019 yang termasuk dalam tindak tutur direktif hanya memiliki satu tujuan, yaitu: Menyarankan (1).

\section{DAFTAR PUSTAKA}

Arikunto. 2013. Prosedur Penelitian: Suatu Pendekatan Praktik. Jakarta: Rineka Cipta.

Departemen Pendidikan Nasional. 2005. Kamus Besar Bahasa Indonesia (edisi ke-3). Jakarta: Balai Pustaka.

Dinari, Irene. Jenis-Jenis Dan Penanda Majas Sarkasme Dalam Novel The Return Of Sherlock Holmes. Prosiding Prasasti, 2015: 489-499.

Djajasudarma. 2012. Wacana dan Pragmatik. Bandung: Refika Aditama.

Herawati, Ida. 2017. Media Sosial Berdampak pada Ekspresi Kebahasaan Masyarakat (Tanggapan Masyarakat Melayu terhadap Pernyataan Efendi Simbolon di Media Sosial). Jurnal Bahasa. 11 (1), 25-34.

Hariyanti, Nunik. Yustitia, Senja. Bahasa dan Ekspresi Politik (Studi Critical Discourse Analysis terhadap Akun Instagram Satir @Nurhadi_Aldo). Jurnal Aristo (Social, Politic, Humaniora). 8 (1), 154-172. 
Juansah, D. Erwin, Bachari D. Andhika. 2017. Pragmatik (Analisis Penggunaan Bahasa). Bandung: Penerbit Prodi Linguistik SPS, Universitas Pendidikan Indonesia.

Jumanto. 2017. Pragmatik: Dunia Linguistik Tak Selebar Daun Kelor Edisi 2. Yogyakarta: Morfalingua.

Kadir, Manjarreki. 2018. "Satire Dalam Puisi "Potret Pembangunan" Karya WS Rendra". Tesis. Program Pascasarjana. Magister Pendidikan Bahasa dan Sastra Indonesia. Universitas Muhammadiyah Makassar.

Keraf, Gorys. 2009. Diksi dan Gaya Bahasa. Jakarta: PT Gramedia Pustaka Utama.

Mahmudah. 2012. Sarkasme Judul Berita Surat Kabar Nasional. Jurnal Retorika. 8 (2), 118-122.

Mahsun. 2005. Metode Penelitian Bahasa. Jakarta: PT Raja Grafindo.

Nurcahyo, Rachmat. 2013. Panduan Debat Bahasa Indonesia 2013 (Modul Pelatihan FLAT - Foreign Language Association UIN Jakarta).

Prasetyono, Dwi Sunar. 2011. Buku Lengkap Majas dan 3000 Peribahasa. Yogyakarta: Diva Press.

Pratama, Hendi dkk. 2018. Panduan Debat Kompetitif. Yogyakarta: Erhaka Utama.

Rahardi, Kunjana. 2007. Berkenalan Dengan Ilmu Bahasa Pragmatik. Malang: Dioma.

Sari, Eka Murti. 2013. Stilistika, Kajian Puitika Bahasa, Sastra, dan Budaya. Yogyakarta: Pustaka Pelajar.
Sudaryanto. 1993. Metode dan Aneka Tehnik Analisis Bahasa (Pengantar Penelitian Wahana Kebudayaan Secara Linguistik). Yogyakarta: Duta Wacana University Press.

Sugiyono. 2007. Metode Penelitian Kuantitatif dan $R \& D$. Bandung: Alfabeta.

Suroso. 2001. Menuju Pers Demokratis: Kritik Atas Profesionalisme Wartawan. Yogyakarta: LSIP.

Tarwiyati, Putri Ayu. Sabardila, Atiqa. 2020. Bahasa Sarkasme Warganet dalam Berkomentar Pada Akun Instagram @ Aniesbaswedan. Jurnal Literasi. 4 (2), 157-168.

Yule, George. 1996. Pragmatik. Yogyakarta: Pustaka Pelajar.

Zaim, M. 2014. Metode Penelitian Bahasa: Pendekatan Struktural. Padang: Sukabina Press. 